\title{
PET によるタウタンパク質病変の画像化
}

認知症の制圧は喫緊の課題であるが，その鍵を握る のが脳内に蓄積する異常タンパク質を標的とした診断 と治療である。代表的な認知症であるアルツハイマー 病では，アミロイド $\beta(\mathrm{A} \beta)$ と夕ウと呼ばれるタンパ ク質が異常な線維状の凝集体を形成して脳内に蓄積す る. $\mathrm{A} \beta$ は細胞外, 夕ウは神経細胞内でそれぞれ老人 斑, 神経原線維変化と呼ばれる病変を形成する。これ らの病変の存在量と分布が一定基準を満たすことで, アルツハイマー病の確定診断がなされるが，別の言い 方をすれば亡くなって脳を解剖しないと確定診断が行 えないことを意味する。

$\mathrm{A} \beta$ や夕ウの蓄積を促進するような遺伝子異常に よって，家族性認知症が発症することから，このよう なタンパク質の蓄積は, 神経細胞死の直接・間接の原 因となると考えられる。家族性アルツハイマー病は $\mathrm{A} \beta$ の異常を引き起こす遺伝子異常が主体であること などから, タウよりも $\mathrm{A} \beta$ を標的とした診断法および 治療法の開発が先行した。 その結果, 老人斑に結合す る放射性薬剤が開発され，薬剤を投与してポジトロン 断層撮影（PET）を行うことで，生体脳でアルツハイ マー病の発症前から老人斑を検出できるようになった. 一方, $\mathrm{A} \beta$ ワクチンをはじめとする抗 $\mathrm{A} \beta$ 治療は, これ まで 15 以上の薬剤が治験で評価されたが, 半数以上 は治験が中断され，薬事承認を得た薬剤はこれまでの ところ存在しない.

こうした治験の状況に加えて, 夕ウの蓄積は $\mathrm{A} \beta$ 蓄 積がなくとも神経細胞死を引き起こすことや, $\mathrm{A} \beta$ で なくタウが蓄積するモデル動物で顕著な神経細胞死が 起こることが見出され, 夕ウを標的とする診断薬・治 療薬の開発に目が向けられるようになった. 夕ウ病変 に結合するPET薬刻としては, FDDNP という化合物 が知られていたが, タウに対してより親和性と選択性 が高い薬剤の開発が求められた。

最近になり, 以下の 3 つの研究グループから, 夕ウ 病変を選択的に高コントラストで画像化する PET薬 剤の開発とヒトへの応用が報告された。(1)放射線医学 総合研究所が開発したPBB3 は, アルッハイマー病の 神経原線維変化のみならず，非アルツハイマー型認知 症で蓄積する夕ウ病変も検出できるため, 様々な認知 症を鑑別するのに有用と考えられる (1). 放射性半減 期が短い ${ }^{11} \mathrm{C}$ で標識されるので, 老人斑 PET と同日に タウ PETを実施可能だが，検査のたびに薬剤を標識合 成する必要がある。(2)東北大学が開発したTHK5105
およびTHK5117 は, アルツハイマー病の神経原線維 変化に強い結合性を有する薬剤である(2). 半減期が 比較的長い ${ }^{18} \mathrm{~F}$ で標識されるので, 一度の標識合成で 複数の被験者を検査可能である。ごく最近, 夕ウ描出 のコントラストを高めたTHK5351 が発表され，注目 を集めている。 GE 社に独占実施権を付与されたこと から，実用化へ向けたさらなる臨床評価は，同社が主 体となって展開される見达みが高い. (3)シーメンス社 が開発し，イーライリリー社・Avid 社が知財を引き継 いだT807（別名 AV1451）は，東北大学の化合物と同 様に ${ }^{18} \mathrm{~F}$ で標識され, アルツハイマー病の神経原線維 変化を選択的に検出しうることが示されている (3). 家族性アルツハイマー病のコホート研究や, 抗 $A \beta$ 療 法を無症候段階のアルツハイマー病患者で試験する研 究など, 米国の多施設研究でこの薬剤による夕ウ PET の実施が計画されている.

これらの PET薬剤を用いた探索臨床 PET 研究では, タウはアルツハイマー病の発症に先立って脳内で記憶 の出し入れに関与する海馬付近で蓄積が始まり, 発症 および進行に伴って大脳の広範な領域に蓄積部位が拡 大することが明らかになった。一方, $A \beta$ は発症前に 大脳の広い範囲で蓄積し, その後は蓄積量も分布も目 立って変化しないことから, 認知機能の進行性の低下 と関係が深いのは夕ウ蓄積であり，A $\beta$ ではなくタウ の PET 画像が発症の切迫性や発症後の進行の客観的 指標をもたらすことが示された.

このように，A $\mathrm{A}$ と夕ウの $\mathrm{PET}$ を組み合わせること で，生きている状態でアルツハイマー病の確定診断や， 認知症の鑑別診断が行える可能性が高まっている. 特 にタウ PETは発症・進行を判定し, 夕ウ蓄積部位から 今後出現しうる症状を予測するのに役立ちうる。多く の製薬企業や研究機関が, 現在タウワクチンなどの抗 夕ウ療法の開発を進めており, それらの治験において, 対象者の選択や治療薬の概念実証, ならびに治療効果 の客観的評価に寄与すると見达まれる.

著者の利益相反 : 樋口真人 (エーザイ株式会社, 大正製薬株 式会社).

\section{文献}

1) Maruyama M, et al. Neuron. 2013;79:1094-1108.

2) Okamura N, et al. Brain. 2014;137:1762-1771.

3) Chien DT, et al. J Alzheimers Dis. 2013;34:457-468.

キーワード：ポジトロン断層撮影, 認知症

放射線医学総合研究所 分子イメージング研究センター（†263-8555 千葉県千葉市稲毛区穴川 4-9-1)

E-mail: mhiguchi@nirs.go.jp 原稿受領日：2015 年 2 月 24 日，依頼原稿

Title: PET imaging of tau lesions Author: Makoto Higuchi 